\title{
WHY CHINESE MOBILE PHONES SELL THEIR PRODUCTS IN INDONESIA
}

\author{
R.A. Aryanti W. Puspokusumo \\ Jurusan Manajemen, Fakultas Ekonomi dan Komunikasi, BINUS University \\ Jln. K.H. Syahdan No. 9, Palmerah, Jakarta Barat 11480
}

\begin{abstract}
This paper mainly discusses about strategy of China mobile phone manufacturer. Based on the interview with the manufacturer's representative, we tried to comprehend the strategy behind the China mobile phone raid in Indonesia. As people know that mobile phone industry keeps on growing day by day, especially by the invention of the Android operating system, an open source OS with integrated capability. By having a free licensed OS, mobile phone manufacturer can focus mainly on their hardware development. Mobile phone industry is getting crowded by the appearance of new players from China. As the result of the interview shown, in short, the manufacturers are growing because of their innovations and ideas to create a new product with competitive price, usage of right media for promotion, and persistence in penetrating the Indonesian market. It is also through this paper that we hoped to invite young entrepreneur to join the manufacturing industry, as it is a fast growing industry that will surely be developed by the fresh ideas of the young generation of Indonesia.
\end{abstract}

Keywords: China mobile phone, manufacturing industry

\begin{abstract}
ABSTRAK
Makalah ini membahas tentang strategi produsen ponsel China. Berdasarkan dari wawancara dengan perwakilan produsen, kami mencoba untuk memahami strategi di balik serangan ponsel China di Indonesia. Seperti yang orang tahu, bahwa industri ponsel terus berkembang hari demi hari, terutama oleh penemuan sistem operasi Android, sebuah OS terbuka dengan kemampuan terintegrasi. Dengan memiliki OS berlisensi gratis, produsen ponsel bisa fokus terutama pada pengembangan perangkat keras mereka. Industri ponsel semakin ramai dengan munculnya pemain baru dari China. Sebagai hasil wawancara yang ditampilkan, singkatnya, produsen tumbuh karena inovasi dan ide untuk menciptakan produk baru dengan harga yang kompetitif, penggunaan media yang tepat untuk promosi, dan ketekunan dalam menembus pasar Indonesia. Melalui tulisan ini juga penulis berharap untuk mengundang pengusaha muda untuk bergabung dengan industri manufaktur karena merupakan industri yang berkembang cepat yang pasti akan dikembangkan dengan ide-ide segar oleh generasi muda Indonesia.
\end{abstract}

Kata kunci: ponsel China, industri manufaktur 


\section{INTRODUCTION}

Ten years ago and mobile phone was not a common gadget to have. Ten years ago and only five out of ten people would have it and brought it on their pocket everywhere. Today, children less than 10 years old had their own phone, teenage had their phone beeping every minute, and adults can do their job easily using mobile phone. Even some people, namely from the mid to low class had their own device as well. Lifestyle, mobility, simplicity, multimedia are some elements of today's mobile phone, not to mention the needs of communication as well. What cause this phenomenon? One of the causes is the raid of the Chinese manufactured mobile phone, Hua Wei, Nexian, K-Touch, Hi-Tech, Sky Bee, Dezzo, Blueberry and not to mention other brands available at the market. By gathering information from three manufacturers using interview method, this research will mainly discussed about the company behind the Chinese product raid.

The aims of this investigation are: (1) to know what are the main features offered by the manufacturer; (2) to know who are the main targets of the products; (3) to know the reason why they choose Indonesia as their marketing target region; (4) to know when they started to market their products in Indonesia; (5) to know where the products are sold, other than Indonesia; and (6) to know the promotion method used.

The benefit of this research is to get a closer look of the China manufacturing company, also to encourage young entrepreneur to join in the mobile phone industry. Our hypothesis is that the company must be empowered with a strong vision of the future, innovation, smart promotion strategy, aiming for everyone at all age without any barrier.

The Investigation will be presented according to the results of the interview. The Paper will be divided into five chapters, introduction, basic theory, research methodology, data analysis and finally conclusion. In the first chapter-Introduction, we will discussed about the background of this research paper, including the research objective, benefit, hypothesis and systematic of investigation. The second chapter will be discussing about basic theory. The third chapter will be the research methodology. In this chapter there will be a desciption of how the datas were taken for the questionnaires. In chapter four it will consist of all the datas collected and also the data analysis. The fifth chapter will be the closing chapter or so to say the conclusion. It will conclude the investigation and prove whether or not the hypothesis is right.

\section{Chinese Mobile Phone}

China is the world's largest mobile communications market. The number of mobile subscribers in China surpassed the number of fixed-line subscribers in 2003. The market itself was transformed in late 2008 into three major full service operators. In addition, China finally issued the long awaited 3G licenses and is poised to become one of the world's major 3G mobile markets. Into 2010, China Mobile continued to be the world's largest mobile operator in terms of number of subscribers. The local development of TD-SCDMA is seeing commercial deployment through China Mobile largely due to the fierce commitment on the part of the government to make sure that China becomes 'a significant player'. This report provides an overview of the mobile market in China, mobile technologies, the huge mobile handset market, mobile data services and popular mobile applications. In addition total mobile subscriber and 3G subscriber forecasts are given to 2015. 


\section{METHOD}

The qualitative research interview seeks to describe and the meanings of central themes in the life world of the subjects. The main task in interviewing is to understand the meaning of what the interviewees say (Kvale, 1996). A qualitative research interview seeks to cover both a factual and a meaning level, though it is usually more difficult to interview on a meaning level (Kvale, 1996). Interviews are particularly useful for getting the story behind a participant's experiences. The interviewer can pursue in-depth information around the topic. Interviews may be useful as follow-up to certain respondents to questionnaires, e.g., to further investigate their responses (McNamara, 1999).

\section{Aspects of Qualitative Research Interviews}

Interviews are completed by the interviewer based on what the respondent says. Interviews are a far more personal form of research than questionnaires. In the personal interview, the interviewer works directly with the respondent. Unlike with mail surveys, the interviewer has the opportunity to probe or asks follow up questions. Interviews are generally easier for respondent, especially if what is sought is opinions or impressions. Interviews are time consuming and they are resource intensive. The interviewer is considered a part of the measurement instrument and interviewer has to be well trained in how to respond to any contingency.

\section{Types of Interviews}

Informal, conversational interview, no predetermined questions are asked, in order to remain as open and adaptable as possible to the interviewee's nature and priorities; during the interview the interviewer "goes with the flow". General interview guide approach - the guide approach is intended to ensure that the same general areas of information are collected from each interviewee; this provides more focus than the conversational approach, but still allows a degree of freedom and adaptability in getting the information from the interviewee. Standardized, open-ended interview - the same openended questions are asked to all interviewees; this approach facilitates faster interviews that can be more easily analyzed and compared. Closed, fixed-response interview - where all interviewees are asked the same questions and asked to choose answers from among the same set of alternatives. This format is useful for those not practiced in interviewing.

\section{Samples}

The samples that we used are three Chinese Mobile Phone company, which are ZTE, Huawei, and Tiphone. The reason why we chose those three companies is because the three of them have sold their products in Indonesia, and their brands are quite famous. Thus, it makes us easier to meet them and interviewed them. The schedule of interview on May 30 ${ }^{\text {th }}, 2011$ and on June $8^{\text {th }}, 2011$.

\section{Method of Collecting Data}

We used interview method by asking some questions to the spokesperson of the companies. The questions' format is $5 \mathrm{~W} 1 \mathrm{H}$ : What, When, Why, Where, Who, and How. The questions will be related to our topic, why Chinese Mobile Phones are selling in Indonesia. The qualitative data will be presented as the answers of every companies. 


\section{RESULT AND DISCUSSION}

\section{ZTE}

ZTE Corporation is a multinational telecommunications equipment and systems company headquartered in Shenzhen, China. As of 2011 it is the second-largest China-based telecoms equipment maker (after Huawei) and the world's fourth-largest mobile phone vendor. ZTE was founded in 1985 and offers a wide variety of telecommunication products, including products that provide value-added services such as video on demand and streaming media, to its customers, are primarily telecommunications service providers, mobile network operators.

ZTE's core products encompass wireless, telephone exchange, access, optical transmission, and data telcom gear, mobile phones and telecommunications software. ZTE is also an OEM, manufacturing products which retail under other brand names. The controversies of ZTE comprise contract negotiation irregularities being brought to light. ZTE, like many large Chinese companies, has its roots in the Chinese State having been created in 1985 by a group of state-owned enterprises associated with China's Ministry of Aerospace. Ties to the state notwithstanding, the corporation is publicly traded having made an initial public offering (IPO) on the Shenzhen stock exchange in 1997 and another on the Hong Kong stock exchange in December, 2004.

While the company initially profited from domestic sales, it vowed to use money from its 2004 Hong Kong IPO to further expand R\&D, overseas sales to developed nations and overseas production. Making headway in the international telecom market in 2006, it took 40\% of new global orders for CDMA networks topping the world CDMA equipment market by number of shipments. That same year also saw ZTE find a customer in the Canadian Telus and membership in the Wi-Fi Alliance. More customers in developed nations soon followed Telus' lead, and in 2007 ZTE had sold to UK's Vodafone, Spain's Telefonica and the Australian Telstra, as well as garnering the greatest number of CDMA contracts, globally. By 2008 ZTE would be able to claim its customer base was truly global, as it had made sales in 140 countries. In 2009 the company had become the worldwide third-largest vendor of GSM telecom equipment, and ZTE sales accounted for about twenty percent of all GSM gear sold throughout the world that year. As of 2011 it holds around 7\% of the key 3GPP Long Term Evolution.

\section{Huawei}

Huawei is a multinational networking and telecommunications equipment company headquartered in Shenzhen, Guangdong, People's Republic of China. It is the largest networking and telecommunications equipment supplier in China and the second-largest supplier of mobile telecommunications infrastructure equipment in the world. Established in 1988 by RenZhengfei, Huawei is a private enterprise which specializes in research and development (R\&D), production and marketing of communications equipment, and providing customized network services for telecom carriers.

Huawei serves 45 of the world's 50 largest telecoms operators and invests around 10 per cent of its annual revenues in R\&D. It has R\&D centers in Beijing, Chengdu, Nanjing, Shanghai, Shenzhen, Wuhan and Xi'an, China; Ottawa, Canada; Bangalore, India; Jakarta, Indonesia; Mexico City, Mexico; Wijchen, Netherlands; Karachi and Lahore, Pakistan, Ferbane, Republic of Ireland; Moscow, Russia; Stockholm, Sweden; Istanbul, Turkey; and Dallas and Silicon Valley, United States.

Huawei was founded by RenZhengfei in 1987, with an initial registered capital of RMB21,000. Established in Shenzhen, Huawei started off as a sales agent for a Hong Kong company 
producing Private Branch Exchange (PBX) switches. By 1990, Huawei began its own independent research and commercialization of PBX technologies targeting hotels and small enterprises.After accumulating knowledge and resources on PBX business, Huawei achieved its first breakthrough into the mainstream telecommunications market in 1992, when it launched its C\&C08 digital telephone switch, which had the largest switching capacity in China at the time. By initially deploying in small cities and rural areas, the company gradually gained market share and made its way into the mainstream market.

In 1994, Huawei established a long distance transmission equipment business, and launched its own HONET integrated access network, combining broadband and narrowband services in a single platform, and SDH product line. Huawei generated sales of RMB1.5 billion in 1995, mainly derived from rural markets in China.

In 1997, Huawei won its first overseas contract, providing fixed-line network products to Hong Kongcompany Hutchison Whampoa.Later that year, Huawei launched its wireless GSM-based products and eventually expanded to offer CDMA and UMTS. In 1999, the company opened a research and development $(\mathrm{R} \& \mathrm{D})$ center in Bangalore, India to develop a wide range of telecom software.From 1998 to 2003, Huawei contracted with IBM for management consulting, and underwent significant transformation of its management and product development structure. After 2000, Huawei increased its speed of expansion into overseas markets, having achieved international sales of more than US\$100 million by 2000 and establishing an R\&D center in Stockholm, Sweden. In 2001, Huawei established four R\&D centers in the United States, divested non-core subsidiary Avansys to Emerson for US\$750 million and joined the International Telecommunications Union (ITU). By 2002, Huawei’s international market sales had reached US\$552 million.

In 2004 Huawei continued its overseas expansion with a contract to build a third-generation network for Telfort, the Dutch mobile operator. This contract, valued at more than \$US25 million, was the first such contract for the company in Europe. In 2005, Huawei's international contract orders exceeded its domestic sales for the first time. Huawei signed a Global Framework Agreement with Vodafone. This agreement marked the first time a telecommunications equipment supplier from China had received Approved Supplier status from Vodafone Global Supply Chain. The agreement established the terms and conditions for the supply of Huawei's solutions to any one of the Vodafone operating companies worldwide. Huawei also signed a contract with British Telecom (BT) for the deployment of its multi-service access network (MSAN) and Transmission equipment for BT's 21Century Network (21CN), providing BT and the UK telecommunications industry with infrastructure necessary to support future growth.

In May 2008, Huawei and Optus developed a mobile innovation centre in Sydney, Australia, providing facilities for engineers to develop new wireless and mobile broadband concepts into "ready for market" products. In 2008, the company embarked on its first large scale commercial deployment of UMTS/ HSPA in North America providing TELUS's new next generation wireless network and Bell Canada with high-speed mobile access. Huawei delivered the world's first LTE/EPC commercial network for TeliaSonera in Oslo, Norway in 2009. The company launched the world's first end-to-end $100 \mathrm{G}$ solution from routers to transmission system that same year, to help meet the rapid growth of network traffic and enhance router efficiency and reliability.

In July 2010, Huawei was included in the Global Fortune 5002010 list published by the U.S. magazine Fortune for the first time, on the strength of annual sales of US\$21.8 billion and net profit of US\$2.67 billion. In late 2010 it was reported that Huawei is planning to invest around US\$500 million (Rs 2,200 crore) to set up a telecom equipment manufacturing facility in Tamil Nadu, India and \$US100 million to expand its R\&D center in Bangalore. 
Huawei has focused on expanding its mobile technology and networking solutions through a number of partnerships. In March 2003, Huawei and 3Com Corporation formed a joint venture company, 3Com-Huawei (H3C), which focused on the R\&D, production and sales of data networking products. The company later divested a 49\% stake in H3C for US\$880 million in 2006. In 2005, Huawei began a joint venture with Siemens, called TD Tech, for developing 3G/ TD-SCDMA mobile communication technology products. The US\$100 million investment gave the company a $49 \%$ stake in the venture, while Siemens held a 51\% stake. In 2007, after Nokia and Siemens co-founded Nokia Siemens Networks, Siemens transferred all shares it held in TD Tech to Nokia Siemens Networks. At present, Nokia Siemens Networks and Huawei hold 51\% and 49\% shares of TD Tech respectively. In 2006, Huawei established a Shanghai-based joint R\&D center with Motorola to develop UMTS technologies. Later that year, Huawei also established a joint venture with Telecom Venezuela, called Industria Electronica Orinoquia, for research and development and sale of telecommunications terminals. Telecom Venezuela holds a 65\% stake while Huawei holds the remaining 35\% stake.

Huawei and American security firm Symantec announced in May 2007 the formation of a joint-venture company to develop security and storage solutions to market to telecommunications carriers. Huawei owns 51\% of the new company, named Huawei Symantec Inc. while Symantec owns the rest. The joint-venture is based in Chengdu. Grameenphone Ltd. and Huawei won the Green Mobile Award at the GSMA Mobile Awards 2009. In March 2009, the Wimax Forum announced four new members to its Board of Directors including Thomas Lee, the Vice Director of the Industry Standards Department at Huawei.

In 2008, Huawei launched a joint venture with UK-based marine engineering company, Global Marine Systems, to deliver undersea network equipment and related services. InApril 2011, Huawei announced an earnings increase of 30\% in 2010, driven by significant growth in overseas markets, with net profit rising to RMB23.76 billion (US\$3.64 billion; £2.23 billion) from RMB18.27 billion in 2009.[26] In 2010 sales outside China continued to be the main driver of Huawei's business. Overseas revenue rose 34\% to RMB120.41 billion in 2010 from RMB90.02 billion in 2009, fueled by regions including North America and Russia. Revenues from China rose 9.7\% to RMB64.77 billion, as the country's big telecom operators reduced their investment last year.

Huawei's revenues of $\$ 78.56$ billion in 2010 in the global carrier-network-infrastructure market put the company second behind the $19.6 \%$ share of Telefon AB L.M. Ericsson, according to market-research firm Gartner.

RenZhengfei is the president of Huawei and has held the title since 1988. Huawei disclosed its list of board of directors for the first time in 2010. Ms. Sun Yafang is chairman of the board. As of 2011, the members of the Board of Directors are Ms. Sun Yafang, Mr. Guo Ping, Mr. XuZhijun, Mr. Hu Houkun, Mr. RenZhengfei,Mr. XuWenwei, Mr. Li Jie, Mr. Ding Yun, Ms. MengWanzhou, Ms. Chen Lifang, Mr. Wan Biao, Mr. Zhang Pingan, and Mr. Yu Chengdong. The members of the Supervisory Board are Mr. Liang Hua, Mr. PengZhiping, Mr. RenShulu, Mr. TianFeng, and Mr. Deng Biao.

\section{Huawei E220 HSDPA USB modem}

Huawei provides fixed network, mobile network, data communications, optical network, software \& services and terminals, including modems, ranging from switching, integrated access network, NGN, xDSL, optical transport, intelligent network, GSM, GPRS, EDGE, W-CDMA, CDMA2000, TD-SCDMA, a full series of routers and other LAN equipment. Huawei manufactures also mobile phones such as the Vodafone 710 and 716, 3G HSDPA cards (Huawei E620 HSDPA Card is being offered by e.g., Vodafone in the United Kingdom and Telia in Sweden), 3G HSDPA USB modem, Huawei E220.and 3G HSUPA modem stick Huawei E172. 
In 2005, Huawei was selected by BT as a preferred supplier of communications equipment for BT's 21CN network strategy; however TalkTalk deployed Huawei MSAN's before this as part of their 21CN network. In the same year, Huawei signed a Global Framework Agreement with Vodafone for mobile network infrastructure. In 2006, Motorola signed a deal with Huawei where Motorola distributes and installs Huawei's 3G equipment. On November 15 (2006), Huawei signed a deal worth 30 million euros (38.4 million USD) with German operator Versatel Holding Deutschland GmbH. Huawei will build a fibre-optic communication network based on Internet protocol (IP) for Versatel, Germany's third largest fixed-line operator. On February 1 (2007), Forbes reported that France Telecom has selected Huawei to supply UMTS mobile equipment for its third generation network Huawei replaced Alcatel/Motorola in Romania, and Nortel in Belgium.

Vodafone awarded Huawei 2007 Global Supplier Award for Outstanding Performance in June, 2007. On October 29, 2007, Huawei announced a WiMAX product. Huawei E960 HSDPA supports two working modes of the wireless gateway and USB modem . It includes four LAN interfaces for the RJ-45, WLAN, telephone interface for the RJ-11, USB interface. The power is supplied through the USB from the PC or power adaptor. Huawei pushes (broadband) Fixed Mobile Convergence (FMC). Leading the company's FMC initiatives is the new Huawei HG553 VoIP home gateway, currently available through Vodafone. The device combines a standard ADSL2 + Wi-Fi-enabled four port router with a pair of phone sockets for VoIP calling and a dockable USB mobile broadband dongle, giving the user a backup option of $3 \mathrm{G}$ data should the fixed-line service fail. Being removable means that the owner can take the mobile broadband service with them when necessary.

The Huawei U121, Playset and the Vodafone 716 are 3G mobile camera phones designed and manufactured by Chinese telecommunications equipment supplier Huawei. The phone is most common in its Vodafone UK form, where it is branded as a Vodafone product, and sold as a budget pay as you talk phone. It's also sold by Polish Play network as Playset.

\section{IDEOS Android entry-level smartphone}

In September 2010, Huawei and Google announced the launch of the Huawei IDEOS smartphone, an entry-level device which will retail for no more than GB£129. It has a Qualcomm 528 $\mathrm{MHz}$ processor, Android 2.2 OS preinstalled, 2.8in QVGA capacitive touchscreen, supports HSDPA tethering to act as a modem connecting to computer, 3.2MP camera, A2DP bluetooth, 512MB internal memory plus acceptance of microSD cards up to 32GB and has its own media player.

\section{Huawei mid-high end Android smartphones}

At CES on the 6th of January, Huawei publicly announced the availability of the X5, a mid level Android 2.2 smartphone. Although targeted as a mid-market phone, as at Q1 2011 the specifications compare favourably with the current high end phones from competing manufacturers. The X5 is powered by a Qualcomm MSM $7230800 \mathrm{MHz}$ processor, with a 3.8" capacitive TFT 480x800 screen, Android 2.2, 11.4mm thick, 5Mp Camera and 720P recording and playback.Pricing was expected to be in the USD\$250-300, severely undercutting comparable phones with similar specifications. Victor Xu the Chief Marketing Officer for Huawei issued a press release at the Consumer Electronics Show (CES) in Las Vegas stating that "The IDEOS X5 will be available in Singapore, Hong Kong and New Zealand beginning January 2011". Apparently this was a paper launch, as at the end of January 2011 the phones were not available for sale in any of the stated countries. However, it has been available for sale in New Zealand since early March and went on sale in Australia on the 16th of March. The US release was slated for Q2 2011, but whether this will be achieved remains to be seen. 
Information has also been released on the Huawei X6. The specifications of this phone are almost identical to those of the X5, however it will have a slightly larger screen at 4.1" and the processor will be clocked at $1 \mathrm{Ghz}$.

\section{Huawei Ideos Tablet S7}

The Huawei Ideos Tablet S7 has a 7 inch touch-screen with $800 * 480$ resolution, it runs Android 2.1, can connect via Wifi, has stereo sound and a gravity sensor. Huawei's global contract sales for 2006 reached 11 billion USD (a 34\% increase from 2005), 65\% of which comes from overseas market. Huawei has now become a leading vendor in the industry and one of the few vendors in the world to provide end-to-end 3G products. In Feb 2009 CTS (Gibraltar) Ltd is due to launch a 3G mobile network. This network is an end-to-end 3G service provided by Huawei. In 2006, Huawei ranked No.1 in the global NGN market (Infonetics), No.1 in mobile softswitch (In-Stat), No. 2 in optical network (Ovum-RHK), No.1 in IP DSLAM (Infonetics), No.2 in broadband convergence routers (Gartner), and No.1 in MSAN market (Infonetics).By the end of 2008, global contract sales of Huawei Technologies, China's largest telecoms gear maker, jumped 46 percent to 23.3 billion USD. Huawei also forecast sales of more than 30 billion USD in 2009.

Huawei Technologies was included in the World's Most Respected 200 Companies list compiled by Forbes magazine in May 2007, one of the six from the telecom industry. In December 2008, BusinessWeek magazine included Huawei in their inaugural list of 'The World's Most Influential Companies' in collaboration with an advisory board of 14 academics, consultants, and industry leaders worldwide, including Shelly Lazarus, Chairman and CEO of Ogilvy \& Mather Worldwide and Jim Collins, author of Good to Great.

In the end of 2008, Huawei has successfully shipped over one billion licenses for its All-IP based mobile softswitch. This significant milestone was reached only five years after Huawei shipped the industry's first mobile softswitch and it is the first time any manufacturer has reached this level. Huawei softswitches are speeding the transformation of mobile networks to All-IP in more than 100 countries. Huawei launched its IP-based mobile softswitch product in 2003 and, in the same year, installed the world's first 3G mobile softswitch with separate architecture in the United Arab Emirates. In 2004, the company created the world's largest IP mobile softswitch network in China.

According to the World Intellectual Property Organization (WIPO) on 27 January 2009, Huawei was ranked as the largest applicant under WIPO's Patent Cooperation Treaty (PCT), with 1,737 applications published in 2008. Overall, the total number of international patent filings under WIPO's PCT for 2008 represents the highest number of applications received under the PCT in a single year and China improved its ranking by one place, to become the sixth largest user of the PCT, with 6,089 filings. In 2010 Fast Company ranked Huawei the fifth most innovative company in the world. In 2010 The Economist recognizes Huawei with its Corporate Use of Innovation Award.

\section{Tiphone}

Many local phone products come \& then collapse. It comes a moment and then gone silent. The most decisive factor in the cell phone business is actually no different from electronics and automotive products. In other words, can not only rely on sales through trading partners in the upstream level. Mobile products require special handling in any way, aside from selling vendor is also important to have education and training to consumers. Hence, a service center (service center) shall be available. Service center is not just true meeting point for improvement (repair) both hardware and software, but it was far from it. Service center is like a place that provides various services from A to Z. 
Based on the terms of that, Tiphone also initiated a customer service center in order to meet all needs. Tiphone which is under the management of PT. Telesindoshop can indeed utilize Telesindoshop outlets that have been spread evenly in various major cities in Indonesia. But the concept is then enriched. Behold now, the design of the room is designed in such a way, attention to architectural trends and comfort of visitors. besides the layout follows the contours of the consumer for no confusion. Tiphone Service Center also ditimpali with colorful decorations and ornaments the walls and the catchy. This course is made for consumers feel at ease and comfortable.

The living room is pretty, soft seat design and contemporary, also made sesejuk room temperature may follow the concept of comfortability, as if you were not in the office room is thick with the feel of the bureaucracy. Service desks on the set are minimalist but its function maksimalis. Invisible computers and its screen is very disturbing the arrangement, but all integrated so that data can be accessed and make a careful record.

Customer service center, would offer a variety of services needed, starting from sales (sales), service and repair (service) and sales of spare parts (spare parts). You can enjoy the displays of mobile phones while then decided to try out before buying. If there are problems with the handset or device, whether software, applications and hardware, the service will be ready to handle and provide solutions. Often customers do not understand the problems they experience, but in Tiphone Service Center officials will give a fairly detailed explanation so that you can understand what is happening with their devices.

A comfortable place and completeness of service, without people skilled in the art as not to provide solutions to consumers. That's why Tiphone highly selective against employees who deal directly with frontliner consumers. Not only smile as needed, but also the understanding of all things that faced by consumers. Both trivial issues that are related to cellular technology. They were very cooperative to open consulted when consumers complained about all the problems. Later when you go home, a relief and satisfaction to be guaranteed.

\section{CONCLUSION}

According to data analysis from the answers we have collected, the three companies offer innovative products to the customers so that they won't lose in the competition and choose Indonesia because of its huge populations. Their target of people differs in terms of classes. Their time in Indonesia is also differs, two of the companies have sold their products outside Indonesia, while one of them has yet to do it. They have their own ways of promoting their products. From what we have learned from the three companies, we can conclude that Chinese Mobile Phones sells their product in Indonesia because Indonesia has huge populations that also has a huge needs of communication devices. The reason why the companies are able to survive is that because they keep innovating with their products so that they can attract customers.

\section{Suggestion}

We suggest that the three companies do more innovations in their products and promote their products more, because nowadays every products is mostly known because of advertisements. When they are able to do that, their companies will get more profits and will be able to survive long enough in Indonesia's Mobile Phone. 


\section{REFERENCES}

Foddy, W. (1993). Constructing questions for interviews. Cambridge University Press.

Kvale, S. (1996). Interviews: An introduction to qualitative research interviewing. Sage.

McNamara, C. (1999). General guidelines for conducting interviews. Minnesota. 